\title{
PENGGUNAAN AIR FERMENTASI STRAWBERRY SEBAGAI NATURAL STARTER DALAM PEMBUATAN SOFT ROLL
}

\author{
Sandra Sanggramasari \\ Sekolah Tinggi Pariwisata Bandung \\ Email: sandra_sanggramasari@yahoo.co.id
}

How to cite (in APA Style): Sanggramasari, S. (2018). Penggunaan air fermentasi strawberry sebagai natural starter dalam pembuatan soft roll. Barista: Jurnal Kajian Bahasa dan Pariwisata, 5(2), Desember 2018, 215-221.

\begin{abstract}
Abstrak: Penelitian ini merupakan kontibusi terhadap perkembangan subtitusi bahan pengganti ragi komersial dalam pembuatan soft roll. Strawberry merupakan bahan alami yang dapat menggantikan ragi komersial dengan cara fermentasikan. Tujuan dari penelitian ini adalah untuk mengetahui tingkat kesukaan masyarakat terhadap soft roll yang menggunakan ragi alami yang berasal dari strawberry. Metode penelitian yang digunakan adalah experimental. Penelitian ini dianalisis menggunakan t-test untuk mengetahui tinggat kesukaan masyarakat terhadap soft roll dari dari segi keseluruhan aspek, flavour, texture dan appearance. Dari hasil t-test untuk tingkat kesukaan, didapatkan hasil bahwa tidak terdapat perbedaan yang signifikan antara soft roll pembanding dengan soft roll experimen dari segi keseluruhan aspek, flavour, texture dan appearance. Sehingga dapat disimpulkan bahwa tidak terdapat pengaruh penggunaan air fermentasi strawberry terhadap hasil uji kesukaan dari segi keseluruhan aspek, flavour, texture dan appearance. Soft roll pembanding dengan penggunaan ragi instan mempunyai tingkat kesukaan lebih tinggi dibandingkan dengan soft roll experimen dengan penggunaan air fermentasi strawberry dari segi flavor. Namun, soft roll experimen dengan penggunaan air fermentasi strawberry lebih disukai keseluruhan aspek, texture dan appearance jika dibandingkan dengan soft roll pembanding dengan penggunaan ragi instan. Selain itu penggunaan ragi alami dapat membuat roti lebih mudah dicerna namun memerlukan waktu fermentasi lebih lama.
\end{abstract}

Keywords: eksperimen produk makanan, roti, ragi, stoberi

\section{THE USE OF WATER FERMENTATION STRAWBERRY AS NATURAL STARTER IN MAKING SOFT ROLL}

\begin{abstract}
This research contributes to the substitution of yeast in soft roll making. Strawberry is a natural ingredient that can substitute commercial yeast. The purpose of this study is to determine the degree of preference in overall aspects, flavor, texture and appearance in the soft roll. The research method is using experimental research. This study is using t-test to know the panelist preference for soft roll in terms of overall aspects, flavor, texture and appearance. From t-test result for preference level, it was found that there was no significant difference between soft roll control with soft roll experiments in terms of overall aspects, flavor, texture and appearance. It can be concluded that there is no effect of the use of strawberry fermented water on the test results of preference in terms of overall aspects, flavor, texture and appearance. Soft roll control with the use of instant yeast has a higher level of preference than soft roll experiment with the use of strawberry fermented water in terms of flavor. However, soft roll experiment with the use of strawberry fermented water is preferred to all aspects, texture and appearance when compared to soft roll control with the use of instant yeast. In addition, the use of natural yeast can make bread easier to digest but requires a longer fermentation time.
\end{abstract}

Keywords: food product experiment, soft roll, yeast, strawberry 


\section{PENDAHULUAN}

Kualitas ragi akan menentukan kualitas dari roti yang dihasilkan. Oleh karena itu ragi yang digunakan haruslah ragi dengan kualitas terbaik. Ragi yang biasa digunakan dalam pembuatan roti adalah ragi komersial yang biasa di jual dipasaran. Namun, Ko (2012) mengatakan bahwa ragi yang digunakan secara komersil sekarang ini dapat mengempukan roti secara cepat, namun terdapat residu disebabkan pada saat. pembuatan ragi tersebut mengunakan bahanbahan anorganik yang sulit dicerna oleh tubuh manusia. Sedangkan, roti yang menggunakan ragi alami memerlukan fermentasi yang cukup lama namun memiliki ketahanan alami terhadap jamur sehingga tidak memerlukan bahan tambahan lainnya. Oleh karena itu roti yang menggunakan ragi alami, bukan hanya memiliki kualitas lebih baik namun juga lebih awet dan tahan lama. Selain awet dan tahan lama, ragi alami juga memiliki manfaat lainnya seperti mudah dicerna, membentuk tekstur yang empuk, memperkaya aroma dan rasa dan menyehatkan (Ko, 2012). Sehingga dapat disimpulkan bahwa dalam pembuatan roti sebaiknya menggunakan ragi alami sebagai bahan pengembangnya.

Pada dasarnya semua jenis sayuran dan buah-buahan dapat dijadikan bahan pembuatan ragi alami (Ko, 2012). Oleh karena itu, buah strawberry juga dapat dijadikan sebagai bahan dalam pembuatan ragi alami. Strawberry merupakan buah yang sangat mudah untuk ditemui, selain rasanya yang enak, harganya juga sangat terjangkau oleh masyarakat Indonesia. Strawberry juga memiliki banyak sekali kandungan yang baik bagi tubuh manusia seperti vitamin dan mineral. Selain itu, pembuatan ragi alami dengan menggunakan strawberry dapat menggunakan strawberry grade rendah atau leftover strawberry yang tidak terjual sehingga dapat memanfaatkan bahan tidak terpakai dan dapat memaksimalkan pendapatan.

\section{TINJAUAN PUSTAKA \\ Soft roll}

Gisslen (2013) membagi produk yang menggunakan ragi dibagi menjadi tiga yaitu lean dough products, rich dough product dan laminated dough product. Lean dough products merupakan produk yang memiliki kandungan lemak dan gula rendah. Rich dough product merupakan produk yang memiliki lebih banyak kandungan lemak, gula dan telur. Sedangkan laminated dough product merupakan produk yang mempunyai lapisan-lapisan lemak pada adonannya.

Soft roll merupakan salah satu produk dari rich dough product sehingga soft roll merupakan roti yang memiliki kandungan lemak, gula dan telur yang tinggi. Soft roll merupakan makanan yang biasanya disajikan ketika sarapan. Seperti yang dikatakan oleh Romeo (2017) bahwa "soft rolls merupakan jenis makanan yang cocok dinikmati untuk sarapan". Lizzy (2017) juga mengatakan bahwa soft roll merupakan roti yang snagat mudah untuk dibuat karena sangat lembut dan cocok untuk sup, salad dan makanan utama

\section{Ragi}

Ragi dapat dikategorikan sebagai jamur, walaupun sifatnya yang bersel tunggal lebih menyerupai organisme bersel satu sehingga tidak terlalu cocok dikategorikan sebagai tumbuhan maupun hewan (DiMuzio, 2010). Ragi berfermentasi dan berkembang biak dengan cara memakan kandungan gula yang biasanya terdapat dalam tepung (Hitz, 2008). Namun DiMuzio (2010) mengatakan bahwa ragi memakan gula seperti glukosa, fruktosa, sukrosa, dan maltose. Ragi menghasilkan enzim mereka sendiri yaitu zimase, untuk membantu mereka memperoleh energi dari gula-gula tersebut, yang kemudian menghasilkan karbon dioksida dan alcohol.

Terdapat banyak sekali jenis dari ragi, namun pada umumnya ragi terbagi menjadi dua yaitu ragi komersial dan ragi alami. Ragi komersial yang biasa digunakan adalah Saccharomyces cerevsiae sedangkan ragi alami yang biasa ditemukan adalah Candida milleri. Pada dasarnya ragi komersial terbagi menjadi tiga, yaitu: active dry yeast/ragi kering, fresh baker's yeast/ragi basah dan instant yeast/ragi instan (Hitz, 2008). Active dry yeast memerlukan hidrasi sebelum digunakan. Sehingga dalam penggunaanya, sebelum dicampurkan dengan bahan lainnya, active dry yeast harus dilarutkan dulu dalam air pada suhu $38^{\circ} \mathrm{C}$ selama kurang lebih lima 
menit. Fresh baker's yeast mengandung tujuh puluh persen air. Dalam penyimpanannya fresh baker's yeast harus disimpan dalam wadah tertutup di lemari pendingin. Penggunaan instant yeast sangat mudah sehingga dapat dicampurkan secara langsung bersama bahan-bahan lainnya, namun memiliki harga yang lebih mahal dibandingkan dengan ragi basah. Sedangkan ragi alami pada dasarnya terbagi menjadi tiga jenis yaitu: liquid starter, refresh starter dan sourdough (Ko, 2016). Liquid starter dibuat dengan mencampurkan buah atau sayur dengan air kemudian memfermentasikannya selema beberapa hari. Roti yang menggunakan liquid starter membutuhkan waktu yang yang lama pada saat proses fermentasi dan adonannya tidak stabil namun hasil akhir roti memiliki aroma yang lebih kuat jika dibandingkan dengan refresh starter. Untuk membuat refresh starter, dapat mencampurkan liquid starter dengan tepung yang akan menghasilkan roti dengan aroma yang lembut. Sedangkan dalam pembuatan sourdough tidak memerlukan liquid starter, namun hanya dengan mencampurkan tepung dengan air saja kemudian memfermentasikannya. Roti dengan penggunaan sourdough akan menghasilkan roti yang berat dan memiliki rasa yang sedikit asam.

Pada dasarnya ragi alami terdapat dalam semua jenis makanan seperti buahbuahan, sayuran, serealia, herbal dan bunga (Ko, 2012). Dari bahan-bahan tersebut kemudian ditambahkan dengan air dan kemudian di fermentasikan selama beberapa hari dalam gelas yang telah disterilkan pada suhu ruang. Setelah beberapa hari, ragi alami dan bakteri asam lactic akan mulai untuk berkembang, sehingga suhu udara harus dijaga dan ragi harus diberi makan secara berkala. Ragi alami ini akan memiliki aroma dan rasa yang khas yang menjadikan roti yang dibuat kaya akan aroma dan rasa.

Dalam pembuatan ragi alami, sebaiknya menggunakan bahan organik karena bahan kimia akan merusak proses fermentasi. Selain itu, perlu diperhatikan pemilihan bahan karena enzim protease dalam buah-buahan seperti nanas, papaya dan kiwi akan merusak gluten sehingga akan mempengaruhi hasil akhir produk roti (Ko, 2016). Oleh karena itu diperlukan proses pemanasan terlebih dahulu untuk menghilangkan enzim protease yang ada dalam bahan pembuatan ragi alami.

Ko (2016) menjelaskan bahwa banyak sekali faktor-faktor yang harus diperhatikan dalam pembuatan ragi alami. Pertama adalah temperature udara harus diperhatikan. Suhu ruang yang paling baik untuk fermentasi adalah $25-27^{\circ} \mathrm{C}$. Temperature dibawah $25^{\circ} \mathrm{C}$ akan membuat proses fermentasi lebih lama dan apabila dibawah $18^{\circ} \mathrm{C}$ maka ragi akan tidak aktif. Apabila suhu ruang diatas $27^{\circ} \mathrm{C}$ maka fermentasi akan lebih cepat dan apabila fermentasi diatas $30^{\circ} \mathrm{C}$ maka ragi alami akan mudah terkontaminasi. Yang kedua adalah dengan menjaga kondisi anaerobic untuk mencegah kontaminasi dari bakteri dan jamur lain. Yang ketiga adalah dengan memberi makan ragi. Ragi akan memakan gula sehingga jumlah kandungan gula harus sangat diperhatikan. Yang terakhir adalah menjaga $\mathrm{pH}$. $\mathrm{Ph}$ optimal dalam pembuatan ragi alami adalah antara 4.2 hingga 4.5 .

\section{Strawberry}

Strawberry dengan spesies Fragraria vesca $L$. merupakan buah yang pertama kali masuk ke Indonesia yang berasal dari Amerika Utara. Sedangkan strawberry yang pertama kali ditemukan berasal dari Chili dengan spesies Fragraria chiloensis (Kesumawati, dkk., 2012). Negara penghasil strawberry terbesar adalah Amerika Serikat diikuti oleh Polandia, Italia, Jepang dan Maxico (Budiman dan Saraswati, 2008). Di Indonesia sendiri strawberry banyak dibudidayakan di daerah Sukabumi, Cianjur, Cipanas, Lembang, Batu, Bedugul dan Ciwidey (Budiman dan Saraswati, 2008). Tanaman strawberry merupakan tanaman subtropis, namun strawberry dapat tumbuh di daerah tropis yang mempunyai elevasi diatas $1000 \mathrm{~m}$ dpl dengan suhu $17-20^{\circ} \mathrm{C}$ (Susanto, dkk., 2010).

Kandungan vitamin $\mathrm{C}$ yang tinggi dalam strawberry yaitu $60 \mathrm{mg}$ per 100 gram. Selain itu, buah strawberry mengandung ellagic acid terutama pada biji dan daunnya. Ellagic acid berperan sebagai antikarsinogen dan antimutagen yang berperan sebagai penghambat kanker akibat dari persenyawaan-persenyawaan kimia berbahaya (Budiman dan Saraswati, 2008). Strawberry juga dikenal sebagai antioksidan 
karena mengandung quercetin, ellagic acid, antosianin dan kaempferol yang berperan mencegah terbentuknya senyawa karsinogen, menghambat proses karsinogenesis dan menekan pertumbuhan tumor (Budiman dan Saraswati, 2008). Strawberry juga mencegah jantung coroner, menekan tekanan darah tinggi, mengatasi masalah pencernaan, hati, murus-murus, rematik, radang sendi, encok, obat jerawat, mempercantik kulit, menjadikan gigi putih dan menghilangkan bau mulut serta meningkatkan kekuatan otak dan penglihatan (Budiman dan Saraswati, 2008).

Strawberry dapat dikonsumsi secara langsung maupun berupa olahannya seperti selai, sirup, kerupuk, sambal, sari buah maupun topping, strawberry juga dapat dijadikan sebagai natural starter. Ko (2016) menjelaskan bahwa buah strawberry dapat diolah menjadi natural starter dengan cara mencampurkannya dengan air kemudian mengfermentasikannya selama satu minggu. Natural starter ini lah yang nantinya menggantikan ragi dalam pembuatan produk makanan beragi maupun roti.

\section{METODE}

Metode penelitian merupakan hal yang sangat penting dalam sebuah penelitian karena apabila data-data dapat diperoleh maka tujuan dari penelitian akan tercapai sehingga masalah dapat terpecahkan. Hal ini sesuai dengan pengertian metode penelitian yaitu "suatu cara ilmiah untuk mendapatkan data dengan tujuan dan kegunaan tertentu" (Sugiono, 2011:3).

Dalam penelitian ini metode penelitian yang digunakan adalah metode penelitian kuantitatif. Metode penelitian kuantitatif merupakan "suatu pendekatan penelitian yang bersifat obyektif, mencakup pengumpulan dan analisis data kuantitatif serta menggunakan metode pengujian statistik" (Hermawan, 2005:19). Penelitian kuantitatif dibagi menjadi dua jenis yaitu penelitian eksperimen dan survei (Hermawan, 2005). Penelitian ini menggunakan jenis penelitian experimen karena metode penelitian experimen akan menghasilkan produk baru sehingga akan meningkatkan kualitas dari produk yang diteliti. Pengertian penelitian eksperimen itu sendiri dapat diartikan sebagai "penelitian yang berusaha mencari pengaruh variable tertentu terhadap variable yang lain dalam kondisi yang terkontrol secara ketat" (Riduwan, 2010:50).

\section{Teknik Pengukuran dan Analisis Data}

Dalam penelitian ini, uji sensori digunakan untuk menilai karakteristik dari soft roll pembanding yang menggunakan ragi instan dengan soft roll experimen yang menggunakan air fermentasi strawberry menggunakan acuan perbandingan uji sensori karakteristik soft roll yang meliputi flavor, texture dan appearance. Uji sensori/uji organoleptic/uji indrawi dapat diartikan sebagai "a scientific method used to evoke, measure, analyze, and interpret those responses to products as perceived through the senses of sight, smell, touch, taste, and hearing" (Stone and Sidel, 2004 dalam Lawless dan Heyman, 2010:2).

Dalam penelitian ini karakteristik dari soft roll dibedakan menjadi tiga seperti yang dijelaskan oleh Figoni (2011) bahwa untuk menilai karakteristik produk dapat dibagi menjadi membaginya menjadi tiga yaitu: flavor, texture dan appearance. Dalam penelitian ini, pengujian sensori hanya akan dilakukan untuk menguji kesukaan dari masyarakat mengenai soft roll yang menggunakan ragi instan dan soft roll yang menggunakan air fermentasi strawberry. Sehingga, pengujian yang paling tepat adalah pengujian afektif dimana panelisnya bukan merupakan panelis ahli. Seperti yang dijelaskan oleh Lawless dan Heyman (2010) bahwa pengujian afektif atau pengujian hedonic digunakan untuk mengukur tingkat kesukaan atau ketidaksukaan dari sebuah produk. Sehingga, dalam pengujian ini akan digunakan Quartermaster 9-point hedonic scale yaitu skala yang dikembangkan oleh U.S. Army Food dan Container Institute. Skala ini dibagi menjadi sembilan bagian yaitu: amat sangat suka, sangat suka, suka, agak suka, biasa/netral, agak tidak suka, tidak suka, sangat tidak suka dan amat sangat tidak suka (like extremely, like very much, like moderately, like slightly neither like nor dislike, dislike slightly, dislike moderately, dislike very much and dislike extremely). Quartermaster 9point hedonic scale merupakan skala yang sangat sederhana dan sangat mudah untuk digunakan. Skala ini merupakan skala yang 
digunakan untuk menentukan derajat kesukaan untuk produk makanan dan merupakan skala yang paling umum digunakan dalam pengujian konsumen terhadap makanan, minuman dan produk selain makanan selama beberapa puluh tahun terakhir (Lawless dan Heyman, 2010). Dalam penelitian ini hanya terdapat dua buah sampel sehingga data akan dianalisis menggunakan analisis statistik parametrik yaitu t-test.

Jumlah panelis dari uji afektif seperti yang dijelaskan Moskowitz, dkk. (2006) bahwa uji kesukaan konsumen yang bertujuan untuk menentukan preferensi keseluruhan, kesukaan terhadap suatu produk atau sifat sensorik produk hanya memerlukan panelis sedikit yaitu 50 hingga 100 panelis. Oleh karena itu jumlah panelis dalam penelitian ini akan diambil sebanyak 50 orang panelis yang tidak terlatih.

\section{Rancangan Percobaan}

Dalam penelitian ini produk eksperimen yang dibuat adalah soft roll dengan menggunakan strawberry sebagai pengganti ragi instan dengan produk pembanding yaitu soft roll dengan menggunakan ragi instan. Strawberry yang telah difermentasikan akan menggantikan ragi instan secara keseluruhan dengan rancangan percobaan yang tertuang pada tabel berikut ini:

Tabel 1

Rancangan Percobaan

\begin{tabular}{|c|c|c|}
\hline & $\begin{array}{c}\text { Soft roll } \\
\text { Pembanding }\end{array}$ & $\begin{array}{c}\text { Soft roll } \\
\text { Experimen }\end{array}$ \\
\hline Ragi instan & $100 \%$ & \\
\hline Strawberry & & $100 \%$ \\
\hline
\end{tabular}

(Hasil Olahan Peneliti, 2018)

\section{Resep}

Dalam penelitian ini, resep pembanding menggunakan resep dari Sekolah Tinggi Pariwisata Bandung yang dijelaskan pada tabel berikut:
Tabel 2 Resep Soft roll

\begin{tabular}{|l|l|l|}
\hline Ingredients & Pembanding & Eksperimen \\
\hline Air & 1000 ml & $600 \mathrm{ml}$ \\
\hline Ragi instan & 32 gram & - \\
\hline Mentega & 50 gram & 50 gram \\
\hline Gula & 120 gram & 120 gram \\
\hline Garam & 35 gram & 35 gram \\
\hline Minyak & 100 gram & 100 gram \\
\hline $\begin{array}{l}\text { Tepung } \\
\text { protein } \\
\text { tinggi }\end{array}$ & 1000 gram & 800 gram \\
\hline $\begin{array}{l}\text { Tepung } \\
\text { protein } \\
\text { sedang }\end{array}$ & 1000 gram & 800 gram \\
\hline Susu bubuk & 100 gram & 100 gram \\
\hline Telur & 5 butir & 5 butir \\
\hline Improver & 15 gram & 15 gram \\
\hline $\begin{array}{l}\text { Refresh } \\
\text { starter }\end{array}$ & - & 800 garm \\
\hline Total & 3702 gram & 3702 gram \\
\hline
\end{tabular}

(Labensky, dkk., 2016)

Cara pembuatannya adalah campur semua bahan kering dalam wadah, kemudian aduk. Tambahkan bahan cair. Setelah adonan menggumpal, tambahkan mentega dan minyak. Aduk hinga adonan kalis. Fermentasikan hingga double size. Keluarkan udara dari dalam adonan. Timbang seberat 50 gram. Bulatkan, fermentasikan selama 20 menit. Kemudian bentuk bulat kembali. Fermentasikan hingga double size. Egg wash. Bakar selama 20 menit dengan suhu $200^{\circ} \mathrm{C}$. Sajikan soft roll.

HASIL DAN PEMBAHASAN Tabel 3 Hasil Uji-t

\begin{tabular}{|c|c|c|c|c|c|}
\hline \multirow[b]{2}{*}{ Aspek } & \multicolumn{2}{|c|}{ Soft Roll A } & \multicolumn{2}{|c|}{ Soft Roll B } & \multirow[b]{2}{*}{ Sig. } \\
\hline & $\begin{array}{c}\text { Mea } \\
\mathrm{n}\end{array}$ & $\begin{array}{c}\text { Standa } \\
\text { rd } \\
\text { Deviati } \\
\text { on }\end{array}$ & $\begin{array}{c}\text { Mea } \\
n\end{array}$ & $\begin{array}{c}\text { Standa } \\
\text { rd } \\
\text { Deviati } \\
\text { on }\end{array}$ & \\
\hline $\begin{array}{l}\text { Keseluru } \\
\text { han }\end{array}$ & $\begin{array}{r}8.08 \\
00 \\
\end{array}$ & 0.6091 & $\begin{array}{r}8.30 \\
00 \\
\end{array}$ & 0.8204 & $\begin{array}{r}0.17 \\
1 \\
\end{array}$ \\
\hline Flavour & $\begin{array}{r}8.42 \\
00 \\
\end{array}$ & 0.6091 & $\begin{array}{r}8.02 \\
00 \\
\end{array}$ & 0.8204 & $\begin{array}{r}0.14 \\
2 \\
\end{array}$ \\
\hline Texture & $\begin{array}{r}8.02 \\
00 \\
\end{array}$ & 0.6543 & $\begin{array}{r}8.12 \\
00 \\
\end{array}$ & 0.5939 & $\begin{array}{r}0.92 \\
3 \\
\end{array}$ \\
\hline $\begin{array}{l}\text { Appearan } \\
\text { ce }\end{array}$ & $\begin{array}{r}8.04 \\
00 \\
\end{array}$ & 0.6376 & $\begin{array}{r}8.12 \\
00 \\
\end{array}$ & 0.6273 & $\begin{array}{r}0.69 \\
6 \\
\end{array}$ \\
\hline
\end{tabular}

(Hasil Olahan Peneliti, 2018) 
Dasar pengambilan keputusan yang digunakan untuk menerima atau menolak hipotesis yaitu:

1. Jika nilai Sig. $<0,05$ maka hipotesis diterima

2. Jika nilai Sig. $>0,05$ maka hipotesis ditolak Hipotesis: "terdapat perbedaan tingkat kesukaan antara soft roll pembanding dan soft roll experimen".

Berdasarkan tabel 3 diketahui bahwa nilai Sig. (2-tailed) sebesar 0,000 >0.05. Maka dapat disimpulkan bahwa "Hipotesis ditolak". Dengan demikian dapat dikatakan bahwa tidak terdapat perbedaan hasil uji kesukaan keseluruhan aspek, flavour, texture dan appearance antara soft roll pembanding dengan soft roll experimen. Karena tidak terdapat perbedaan yang signifikan maka dapat dikatakan bahwa "tidak terdapat pengaruh penggunaan air fermentasi strawberry terhadap hasil uji kesukaan keseluruhan aspek, flavour, texture dan appearance pada soft roll".

Dari mean menunjukan bahwa soft roll experimen dengan penggunaan air fermentasi strawberry mempunyai tingkat kesukaan lebih tinggi (mean=8.3) dibandingkan dengan soft roll experimen dengan penggunaan ragi instan (mean=8.08) dalam keseluruhan aspek. Namun, dari aspek flavour, mean menunjukan bahwa soft roll pembanding dengan penggunaan ragi instan mempunyai tingkat kesukaan lebih tinggi (mean $=8.42$ ) dibandingkan dengan soft roll experimen dengan air fermentasi strawberry ( mean $=8.02)$. sedangkan dari segi texture, mean menunjukan bahwa soft roll experimen dengan penggunaan air fermentasi strawberry mempunyai tingkat kesukaan lebih tinggi (mean $=8.12$ ) dibandingkan dengan soft roll pembanding dengan penggunaan ragi instan ( mean $=8.02$ ). Pada aspek appearance, mean menunjukan bahwa soft roll experimen dengan penggunaan air fermentasi strawberry mempunyai tingkat kesukaan lebih tinggi (mean $=8.12$ ) dibandingkan dengan soft roll pembanding dengan penggunaan ragi instan (mean = 8.04).

\section{SIMPULAN}

Air fermentasi strawberry dapat dijadikan sebagai alternative pengganti ragi instan dalam pembuatan soft roll. Penggunaan ragi komersial memerlukan waktu fermentasi roti selama seratus menit sedangkan fermentasi pada roti dengan penggunaan ragi alami memerlukan waktu lebih lama. Tidak terdapat perbedaan hasil akhir pada produk soft roll pembanding dan soft roll experiment. Pada hasil Uji-t untuk tingkat kesukaan, didapatkan hasil bahwa tidak terdapat perbedaan yang signifikan antara soft roll experimen dengan soft roll pembanding dari segi keseluruhan aspek, flavour, texture dan appearance. Sehingga kesimpulan akhir dari analisis yang dilakukan dengan Uji-t yaitu tidak terdapat pengaruh penggunaan air fermentasi strawberry terhadap hasil uji kesukaan dari segi keseluruhan aspek, flavour, texture dan appearance. Soft roll pembanding dengan penggunaan ragi instan mempunyai tingkat kesukaan lebih dibandingkan dengan soft roll experimen dengan penggunaan air fermentasi strawberry dari segi flavor. Namun dari keseluruhan aspek, texture dan appearance soft roll experimen dengan penggunaan air fermentasi strawberry lebih disukai dari soft roll pembanding dengan penggunaan ragi instan.

\section{DAFTAR PUSTAKA}

Budiman, S., \& Saraswati, D. (2008). Berkebun Strawberry Secara Komersial. Jakarta: Penebar Swadaya.

Di Muzio, D. (2010) Bread baking: an artisan's perspective. New Jersey: John Wiley \& Sons, Inc.

Figoni, P. (2011) How Baking Works (third edition) New Jersey: John Wiley and Sons, Inc.

Giampieri, F., Tulipani, S., Suarez, A., Quiles, J., Mezzetti, B., \& Battino, M. (2012) The strawberry: Composition, nutritional quality, and impact on human health. Nutrition (28). Pp. 9-19

Gisslen, W. (2013) Professional Baking. New Jersey: John Wiley \& Sons, Inc.

Hermawan, A. (2005) Penelitian Bisnis: Paradigma Kuantitatif. Jakarta: PT. Grasindo. 
Hitz, C. (2008) Baking artisan bread : 10 expert formulas for baking better bread at home. Beverly Massachusetts: Quarry Books.

Kerlinger. (2006). Asas-asas Penelitian Behavioral. Edisi Ketiga. Yogyakarta: Gajah Mada University Press.

Kesumawati, E., Hayati, E., \& Thamrin, M. (2012) Pengaruh naungan dan varietas terhadap pertumbuhan dan hasil tanaman stroberi di dataran rendah. Jurnal Agrista. Vol. 16 No. 1

Ko, Sangjin. (2012) Rahasia Membuat Roti Sehat dan Lezat dengan Ragi Alami. Jakarta: Kawah Media.

Labensky, S. Martel, P., \& Damme, E. (2016) On Baking: a textbook of baking and pastry fundamentals. New Jersey: Pearson Education, Inc.

Lawless, H., \& Heymann, H. (2010) Sensory Evaluation of Food: Principles and Practice. Spinger: London

Lizzy, T. (n.d). Buttery Soft Roll [Online] Diakses dari: $<$ https://www.tastesoflizzyt.com/butte ry-soft-rolls/> [Diakses Tanggal 29 Juli 2018].

Mardiana (2015) Kebun Strawberry Ciwidey Wisata Petik Strawberry [Online] Diakses dari: <http://wisata-bandungselatan.blogspot.com/2015/04/kebunstrawberry-ciwidey.html> [Diakses Tanggal 29 Juli 2018].

Moskowitz, H., Beckley, J., \& Resurreccion, A. (2006) Sensory and Consumer Research in Food Product Design and Development. Blackwell Publishing: Iowa

Nurhayati, R. (2016) Menjadikan pola hidup sehat sebagai gaya hidup. Kompasiana. [Online] Diakses dari: <https://www.kompasiana.com/nunun gsuryani/58443344319773870b33cf3 2/menjadikan-pola-hidup-sehatsebagai-gaya-hidup?page=all $>$ [Diakses Tanggal 29 Juli 2018].

Oktarina, D., Armaini, \& Ardian (2017) Pertumbuhan dan produksi stroberi (fragraria sp) dengan pemberian berbagai konsentrasi pupuk organic cair (poc) secara hidroponik substrat. Jom Faperta UR. Vol 4. No. 1

Romeo. (2016). Soft Roll Bread [Online] Diakses <http://resep.id/view/rms151010000 00000045/Soft-Roll-Bread> [Diakses Tanggal 29 Juli 2018].

Stone, H., \& Sidel, J. (2004) Sensory Evaluation Practices. Academic: San Deigo. Dalam Lawless, H. dan Heymann, H. (2010) Sensory Evaluation of Food: Principles and Practice. Spinger: London

Susanto, S., Hartanti, B., \& Khumaida, N. (2010) Produksi dan Kualitas Buah Stroberi pada Beberapa Sistem Irigasi. Jurnal Hortikultura Indonesia 1(1) 1-9.

Wahidah, et al. (2017) Viabilitas mikroba, pH, kadar alkohol, daya kembang dan volume gas adonan roti manis pada proses pembuatan yeast segar berbahan dasar sirsak. Fakultas Peternakan dan Pertanian. Universitas Diponegoro. 